DOCTRINA

\title{
Libertad de expresión, libertad religiosa y censura cinematográfica. ¿Protección o afectación de garantías fundamentales? Una mirada desde los sistemas interamericano y europeo
}

\author{
Freedom of expression, religious freedom and cinematographic censorship. \\ Protection or impairment of fundamental guarantees? A point of view \\ from the Inter-American and European Court of Human Rights
}

\section{María Fernanda Ekdahl Escobar \\ Abogada, Tribunal Constitucional de Chile}

\begin{abstract}
RESUMEN El trabajo pone de relieve la constante confrontación que existe entre el derecho a la libertad de expresión y el derecho a la libertad religiosa, en los términos expuestos en la Convención Americana de Derechos Humanos y en el Convenio Europeo de Derechos Humanos, particularmente a través de la censura cinematográfica, en aras de lo cual se analizan y refieren diversos pronunciamientos jurisprudenciales de dichos organismos internacionales, en los que, no obstante tratarse de circunstancias similares, estas garantías fundamentales adquieren alcances y matices distintos.
\end{abstract}

PALABRAS CLAVE Libertad de expresión, libertad religiosa, censura cinematográfica, Corte Interamericana de Derechos Humanos, Tribunal Europeo de Derechos Humanos.

ABSTRACT The work highlights the constant confrontation between the right to freedom of expression and the right to religious freedom, in the terms set forth in the American Convention on Human Rights and in the European Convention on Human Rights, particularly through cinematographic censorship, for the sake of which are analyzed and refer to various jurisprudential pronouncements of these international organizations, in which, despite being similar circumstances, these fundamental guarantees acquire different scopes and nuances.

KEYWORDS Freedom of expression, religious freedom, cinematographic censorship, Inter-American Court of Human Rights, European Court of Human Rights. 


\section{Introducción}

Asistimos a los tiempos de la globalización, de la inmediatez en las comunicaciones, de un mundo al alcance, más pequeño de lo que fuera antaño, con múltiples intervinientes, tanto en planos locales, nacionales como internacionales. Hay un nuevo escenario y los actores tienen nuevos papeles; devienen múltiples procesos tanto económicos, como el aumento del volumen y de variedad en las transacciones fronterizas de bienes y servicios, así como el de la difusión acelerada y generalizada de las tecnologías de la comunicación, con una alta interdependencia entre los países.

Los órdenes jurídicos nacionales coexisten con otros, de nivel supra o internacional, generándose complejas interacciones entre sí, lo cual ha provocado diversos y profundos fenómenos transformadores, cambios de paradigmas, que han afectado la concepción tradicional de Estado Nacional, así como al derecho en general y el constitucional en particular, tanto en lo que respecta a sus alcances, la manera de entenderlo, su afectación por los tratados internacionales de derechos humanos, de la aplicación que hacen de los mismos los órganos internacionales, y de la recepción en el derecho interno, del derecho internacional, dando lugar a lo que se conoce como la «internalización del derecho constitucional», que refiere al fenómeno por el cual el derecho constitucional de los Estados Nacionales se ve influido en su contenido y estructuras por el derecho internacional (Serna de la Garza, 2013: 4).

Al decir de Anderson, «es menester reconfigurar la comprensión del derecho constitucional y de los derechos constitucionales de acuerdo al paradigma del pluralismo jurídico, lo cual nos permite entender y responder de mejor forma a los retos actuales del constitucionalismo en la era de la globalización» (Anderson, 2005:3).

En este orden de ideas, Häberle postula un modelo de pluralismo, que a su juicio se manifiesta como «multiplicidad de ideas e intereses, o viceversa, en el seno de una determinada comunidad política, dentro de los parámetros del aquí y ahora. Esta multiplicidad de facetas se nutre de todo un amplio abanico de procedimientos formalmente bien diferenciados y con diferentes grados respecto de su efectividad. Ese conjunto de ideas hace referencia a supuestos fácticos y a valores, concretándose en situaciones de consenso o de conflicto en el seno de las sociedades democráticas. La tensión dialéctica permanente en la que se desenvuelven estos fenómenos e ideas conduce a determinadas alternativas. El pluralismo implica básicamente la «apertura» del sistema constitucional: sus teorías y doctrinas, sus interpretaciones e intérpretes - sobre todo a nivel de derechos fundamentales-, y su inherente dogmática jurídica, junto con su posterior desarrollo y progresos» (Häberle, 2002: 103).

Este trabajo no pretende, en caso alguno, abordar la temática de la globalización y su impacto en el Estado, pues ello excedería con creces su propósito. En efecto, situados en el contexto que referí previamente, de un mundo globalizado y sus transformaciones, me interesa abordar acotadamente lo relativo a un derecho fundamental 
particular, el de la libertad de pensamiento y expresión, para comentar sobre los diversos alcances y matices que ésta puede adquirir, en circunstancias similares, desde la mirada de organismos internacionales, tanto del sistema interamericano como del europeo, como lo son en este caso la Corte Interamericana de Derechos Humanos y el Tribunal Europeo de Derechos Humanos (CIDH y TEDH, respectivamente).

Y refiero especialmente en este análisis a la libertad de pensamiento y expresión, por cuanto se enmarca dentro de los derechos fundamentales y constituye un atributo fundamental de toda persona, y en especial de una sociedad democrática, sin que hoy por hoy se pueda concebir un Estado democrático que dé la espalda a la libertad de expresión.

El desarrollo de este trabajo se abocará al análisis del distinto alcance y sentido que puede adquirir la libertad de expresión, a través del diverso enfoque que, en situaciones concretas similares, tienen los organismos internacionales a los que les compete entender, interpretar y aplicar el derecho. Particularmente, en los casos que comentaré, en relación con la eventual afectación de la libertad de expresión a través de la censura, concretamente la cinematográfica.

\section{Libertad de expresión en el sistema interamericano}

El artículo 13 de la Convención Interamericana de Derechos Humanos ${ }^{1}$ consagra la libertad de pensamiento y de expresión. Desde sus primeros pronunciamientos es posible advertir una firme postura de la Corte Interamericana en defensa de esta garantía, en las que hace hincapié en que quienes están bajo la protección de la Convención tienen el derecho de buscar, recibir y difundir información e ideas de toda índole, así

1. Artículo 13 de la Convención Interamericana de Derechos Humanos consagra la Libertad de Pensamiento y de Expresión: «1. Toda persona tiene derecho a la libertad de pensamiento y de expresión. Este derecho comprende la libertad de buscar, recibir y difundir informaciones e ideas de toda índole, sin consideración de fronteras, ya sea oralmente, por escrito o en forma impresa o artística, o por cualquier otro procedimiento de su elección. [...] 2. El ejercicio del derecho previsto en el inciso precedente no puede estar sujeto a previa censura sino a responsabilidades ulteriores, las que deben estar expresamente fijadas por la ley y ser necesarias para asegurar: a) el respeto a los derechos o a la reputación de los demás, o b) la protección de la seguridad nacional, el orden público o la salud o la moral públicas. [...] 3. No se puede restringir el derecho de expresión por vías o medios indirectos, tales como el abuso de controles oficiales o particulares de papel para periódicos, de frecuencias radioeléctricas, o de enseres y aparatos usados en la difusión de información o por cualesquiera otros medios encaminados a impedir la comunicación y la circulación de ideas y opiniones. [...] 4. Los espectáculos públicos pueden ser sometidos por la ley a censura previa con el exclusivo objeto de regular el acceso a ellos para la protección moral de la infancia y la adolescencia, sin perjuicio de lo establecido en el inciso 2. [...] 5. Estará prohibida por la ley toda propaganda en favor de la guerra y toda apología del odio nacional, racial o religioso que constituyan incitaciones a la violencia o cualquier otra acción ilegal similar contra cualquier persona o grupo de personas, por ningún motivo, inclusive los de raza, color, religión, idioma u origen nacional». 
como el derecho a conocer las opiniones e información de los demás, confiriéndole con ello a la libertad de expresión una doble dimensión, tanto individual como colectiva, por las que implica, de una parte, que nadie puede ser arbitrariamente menoscabado o impedido de manifestar sus propios pensamientos e ideas, $y$, de otra, que toda persona tiene derecho colectivo a conocer la expresión del pensamiento ajeno. ${ }^{2}$

A partir de la Opinión Consultiva OC-5 de 1985, la Corte comenzó a referirse a la libertad de expresión, para construir desde ahí una sólida base argumental por medio de la cual busca dar protección efectiva a esta garantía, así como dar a conocer a los Estados y a la sociedad en general ciertas hipótesis de las cuales pueden derivarse infracciones al artículo 13 de la Convención Americana.

Este pronunciamiento constituye un hito en la materia, y en él la Corte realiza un amplio estudio sobre el contenido y los límites de la libertad de expresión, las circunstancias en las cuales la Convención autoriza su restricción, y la correlación que debe existir entre derechos y deberes, estableciendo al efecto estándares vigentes hasta la fecha.

El asunto tuvo lugar a partir de la solicitud efectuada en 1985 por el gobierno de Costa Rica a la Corte Interamericana, a fin de que dicho organismo emitiera una opinión consultiva sobre la interpretación de los artículos 13 y $29^{3}$ de la Convención Americana sobre Derechos Humanos, en relación con la colegiación obligatoria de los periodistas y la compatibilidad de legislaciones locales con dichas normas, en tanto establecían la obligatoriedad de la colegiación y el título universitario para el ejercicio del periodismo. ${ }^{4}$

2. Sentencias de la Corte Interamericana de Derechos Humanos: Opinión Consultiva OC-5 «La colegiación obligatoria de periodistas», párrafo trigésimo, 13 de noviembre de 1985; Olmedo Bustos y otros contra Chile, «La última tentación de Cristo», serie C-73, párrafo sexagésimo cuarto, 5 de febrero de 2001; Ivcher Bronstein contra Perú, serie C-74, párrafo 146, 6 de febrero de 2001; Herrera Ulloa contra Costa Rica, serie C-107, párrafo 108, 2 de julio de 2004; Ricardo Canese contra Paraguay, serie C-111, párrafo 77, 31 de agosto de 2004).

3. Artículo 29 de la Convención Interamericana. Normas de Interpretación: «Ninguna disposición de la presente Convención puede ser interpretada en el sentido de: a) permitir a alguno de los Estados Partes, grupo o persona, suprimir el goce y ejercicio de los derechos y libertades reconocidos en la Convención o limitarlos en mayor medida que la prevista en ella; b) limitar el goce y ejercicio de cualquier derecho o libertad que pueda estar reconocido de acuerdo con las leyes de cualquiera de los Estados Partes o de acuerdo con otra convención en que sea parte uno de dichos Estados; c) excluir otros derechos y garantías que son inherentes al ser humano o que se derivan de la forma democrática representativa de gobierno, y d) excluir o limitar el efecto que puedan producir la Declaración Americana de Derechos y Deberes del Hombre y otros actos internacionales de la misma naturaleza».

4. En Latinoamérica dichas exigencias están en declinación en los últimos tiempos. Así, de los nueve países en que la colegiación de los periodistas es obligatoria - Brasil, Colombia, Costa Rica, Ecuador, Haití, Honduras, Panamá, Perú y Venezuela-, solo en dos ellos la aplicación de la colegiatura es rigurosa: Costa Rica y Venezuela. En el resto, los requisitos son cada vez más flexibles. Tanto en Nicaragua 
La polémica en torno a si debían o no existir colegios obligatorios, facultados para prohibir el ejercicio del periodismo a quienes no eran miembros de los mismos, fue planteada en relación con el caso de un periodista norteamericano, quien había sido demandado por el Colegio de Periodistas de Costa Rica por ejercicio ilegal de la profesión. Tras el fallo en su contra emitido por la Corte Suprema de Costa Rica, la Sociedad Interamericana de Prensa solicitó la opinión de la Corte Interamericana de Derechos Humanos.

La Corte se manifestó contraria a cualquier regulación, y en su fallo consultivo del 13 de noviembre de 1985, señaló:

La colegiación obligatoria de periodistas, en cuanto impida el acceso de cualquier persona al uso pleno de los medios de comunicación social como vehículo para expresarse o para transmitir información, es incompatible con el artículo 13 de la Convención Interamericana sobre Derechos Humanos (Sentencia de la Corte Interamericana de Derechos Humanos, Opinión Consultiva OC-5, punto primero de la parte resolutiva, 13 de noviembre de 1985).

Expresa su desconfianza en que la colegiación sea la manera correcta de garantizar una información objetiva y veraz a través de un régimen de ética y responsabilidad profesionales. Estableció:

Resulta en principio contradictorio invocar una restricción a la libertad de expresión como un medio para garantizarla, porque es desconocer el carácter radical y primario de este derecho como inherente a cada ser humano, aunque atributo, igualmente, de la sociedad en su conjunto. Un sistema de control al derecho de expresión en nombre de una supuesta garantía de la corrección y veracidad de la información que la sociedad recibe, puede ser fuente de grandes abusos y, en el fondo, viola el derecho a la información que tiene esa misma sociedad (Sentencia de la Corte Interamericana de Derechos Humanos, Opinión Consultiva OC-5 «La colegiación obligatoria de periodistas», párrafo septuagésimo séptimo, 13 de noviembre de 1985).

En cuanto a la "profesionalización» del periodismo por medio de la colegiatura obligatoria, la Corte fue categórica:

no es compatible con la Convención una ley de colegiación de periodistas que impida el ejercicio del periodismo a quienes no sean miembros del colegio y limite el acceso a éste a los graduados en una determinada carrera universitaria. Una ley semejante contendría restricciones a la libertad de expresión no autorizadas por el artículo 13.2 de la Convención y sería, en consecuencia, violatoria tanto del derecho

como en República Dominicana la obligatoriedad ha sido eliminada en los últimos años. No obstante, en El Salvador, Guatemala, Chile y Argentina han habido mociones legales para introducir esas obligaciones y establecer la colegiatura obligatoria. 
de toda persona a buscar y difundir informaciones e ideas por cualquier medio de su elección, como del derecho de la colectividad en general a recibir información sin trabas (Sentencia de la Corte Interamericana de Derechos Humanos, Opinión Consultiva OC-5 «La colegiación obligatoria de periodistas», párrafo octogésimo primero, 13 de noviembre de 1985).

La Corte sostuvo que conforme al artículo 13 de la Convención, la libertad de pensamiento y expresión comprende la de buscar, recibir y difundir informaciones e ideas de toda índole. Por tanto, cuando se restringe ilegalmente la libertad de expresión de un individuo, no solo es el derecho de éste el que está siendo violado, sino también el derecho de todos a recibir ideas. Se ponen así de manifiesto las dos dimensiones de la libertad de expresión.

Asimismo, planteó la indivisibilidad de la expresión y la difusión, de modo que una restricción de las posibilidades de divulgación representa directamente, y en la misma medida, un límite al derecho de expresarse libremente, en tanto, para el ciudadano común tiene tanta importancia el conocimiento de la opinión ajena o de la información de que disponen otros como el derecho de difundir la propia. Al respecto precisó:

La expresión y la difusión del pensamiento y de la información son indivisibles, de modo que una restricción de las posibilidades de divulgación representa directamente, y en la misma medida, un límite al derecho de expresarse libremente. De allí la importancia del régimen legal aplicable a la prensa y al status de quienes se dediquen profesionalmente a ella (Sentencia de la Corte Interamericana de Derechos Humanos, Opinión Consultiva OC-5 «La colegiación obligatoria de periodistas», párrafo trigésimo primero, 13 de noviembre de 1985; Palamara Iribarne contra Chile, serie C-135, 22 de noviembre de 2005).5

Ahora bien, en este orden de ideas, el inciso segundo del artículo 13 de la Convención, junto con prohibir la censura previa, regula la responsabilidad ulterior de los Estados por el ejercicio abusivo de este derecho y prevé restricciones al mismo, las que tienen un carácter excepcional. En tal sentido ha afirmado que, dada la importancia de la libertad de expresión en una sociedad democrática, el Estado no solo debe minimizar las restricciones a la circulación de la información, sino también equilibrar la participación de las distintas informaciones en el debate público, impul-

5. En el mismo sentido, en el caso Palamara Iribarne contra Chile, la Corte sostuvo que para que el Estado garantizara efectivamente el ejercicio del derecho a la libertad de pensamiento y expresión del Sr. Palamara, no bastaba con que permitiera que escribiera sus ideas y opiniones, sino que tal protección comprendía el deber de no restringir su difusión de forma tal que pudiera distribuir su obra, en ese caso un libro, utilizando cualquier medio apropiado para hacer llegar tales ideas y opiniones al mayor número de destinatarios, y que éstos pudieran recibir tal información. 
sando el pluralismo informativo, asegurando condiciones estructurales que permitan la expresión equitativa de las ideas (Gullco, 2009: 4). Conforme a ello, ha realzado la relevancia del caso particular para determinar si una restricción ha sido establecida legítimamente, sujetándose a dicho margo legal, afirmando en tal sentido:

al evaluar una supuesta restricción o limitación a la libertad de expresión, el Tribunal no debe sujetarse únicamente al estudio del acto en cuestión, sino que debe igualmente examinar dicho acto a la luz de los hechos del caso en su totalidad, incluyendo las circunstancias y el contexto en los que éstos se presentaron (Sentencia de la Corte Interamericana de Derechos Humanos, Ivcher Bronstein contra Perú, párrafos centésimo quincuagésimo cuarto y centésimo quincuagésimo quinto, 6 de febrero de 2001).

Al sancionar a los Estados que han incumplido su obligación de garantizar y respetar la libertad de expresión, la Corte hace hincapié en el rol esencial que cumple esta garantía fundamental en la construcción de sociedades abiertas, democráticas, donde cada persona tiene derecho tanto a expresar sus opiniones como a recibir información, ideas, así como el derecho de acceso a las mismas. Así, ha señalado que la libertad de expresión, como pilar angular de una sociedad democrática, es una condición para que ésta se encuentre lo suficientemente informada. ${ }^{6}$ Refiere en este sentido a los medios de comunicación, advirtiendo que tampoco sería admisible que, sobre la base del derecho a difundir informaciones e ideas, se constituyeran monopolios públicos o privados sobre los medios de comunicación para intentar moldear la opinión pública según un solo punto de vista.

Como indica el Informe de la Oficina del Relator Especial para la Libertad de Expresión ${ }^{7}$ (1998: volumen 3), la libertad de expresión es el contrapeso fundamental que permite obtener y difundir opiniones e información, fortaleciendo la sociedad civil y creando posibilidades de participación para los individuos. Precisa a estos efectos que en muchos estados de América sigue existiendo una legislación anacrónica

6. Sentencias de la Corte Interamericana de Derechos Humanos: Olmedo Bustos y otros contra Chile, «La última tentación de Cristo», párrafos sexagésimo octavo y sexagésimo noveno, 5 de febrero de 2001; Ivcher Bronstein contra Perú, párrafo centésimo quincuagésimo segundo; 6 de febrero de 2001; Herrera Ulloa contra Costa Rica, serie C-107, párrafos centésimo décimo segundo, centésimo décimo tercero y centésimo décimo sexto, 2 de julio de 2004.

7. La oficina del Relator Especial fue creada en 1998 por la Comisión Interamericana para proteger y promover la libertad de expresión en las Américas. En octubre del 200o, la Comisión -interpretando la Convención Americana - adoptó la Declaración de Principios sobre la Libertad de Expresión para guiar las actividades del Relator; entre las principales se incluyen: la elaboración de informes generales e informes especiales temáticos, la creación de una red hemisférica para la protección de la libertad de expresión, visitas a los Estados miembros de la OEA a fin de observar la situación de la libertad de expresión, y su promoción. 
en materia de libertad de expresión, incompatible con la Convención Americana y otros instrumentos internacionales de derechos humanos. Menciona, para ilustrar esta situación, los casos de Panamá y Chile, señalando al efecto que en Chile existen leyes con disposiciones que limitan claramente la libertad de expresión. Refiere como ejemplos a los artículos 263 y 264 del Código Penal, al artículo 284 del Código Militar de Justicia y al artículo 6 letra b) de la Ley de Seguridad del Estado, ${ }^{8}$ precisando sobre esta última norma

que varios funcionarios chilenos han utilizado esta disposición contra las personas que han sido críticas de ellos. Por ejemplo, el 13 de abril de 1999, la Corte de Apelaciones de Santiago, en aplicación de la Ley de Seguridad del Estado, prohibió, sobre la base de una solicitud de Servando Jordán, miembro de la Corte Suprema y expresidente de dicho órgano, El Libro Negro de la Justicia Chilena, escrito por la periodista Alejandra Matus. Los miembros de la policía civil se apoderaron de todas las copias de las oficinas de Editorial Planeta. También se apoderaron de copias de las librerías del país (Informe de la Oficina del Relator Especial para la Libertad de Expresión, 1998: volumen 3).

8. El artículo 263 del Código Penal se encuentra actualmente derogado, en virtud de la Ley20.048 de 2005. La norma señalaba: «El que de hecho o de palabra injuriare gravemente al Presidente de la República, o a alguno de los cuerpos colegisladores o a las comisiones de éstos, sea en los actos públicos en que los representan, sea en el desempeño de sus atribuciones particulares, $\mathrm{o}$ a los tribunales superiores de justicia, será castigado con reclusión menor en sus grados medio a máximo y multa de ciento a mil pesos. [...] Cuando las injurias fueren leves, las penas serán reclusión menor en su grado mínimo y multa de ciento a quinientos pesos, o simplemente esta última». El artículo 264 del Código Penal señala: «El que amenace durante las sesiones de los cuerpos colegisladores o en las audiencias de los tribunales de justicia a algún diputado o senador o a un miembro de dichos tribunales, o a un senador o diputado por las opiniones manifestadas en el Congreso, o a un miembro de un tribunal de justicia por los fallos que hubiere pronunciado o a los Ministros de Estado u otra autoridad en el ejercicio de sus cargos, será castigado con reclusión menor en cualquiera de sus grados. [...] El que perturbe gravemente el orden de las sesiones de los cuerpos colegisladores o de las audiencias de los tribunales de justicia, u ocasionare tumulto o exaltare al desorden en el despacho de una autoridad o corporación pública hasta el punto de impedir sus actos, será castigado con la pena de reclusión menor en su grado mínimo y multa de seis a diez unidades tributarias mensuales, o solo esta última». El artículo 284 del Código Militar de Justicia señala: «El que amenazare en los términos del artículo 296 del Código Penal, ofendiere o injuriare de palabra o por escrito o por cualquier otro medio a las Fuerzas Armadas, sus unidades, reparticiones, armas, clases o cuerpos determinados, o a uno de sus integrantes con conocimiento de su calidad de miembro de esas instituciones, será sancionado con la pena de presidio menor en su grado mínimo a medio». El artículo 6 letra b) de la Ley de Seguridad del Estado, fue modificado por la letra a) del artículo 46 de la Ley19.733 de 2001. Su texto original señalaba: «Cometen delito contra el orden público: b) Los que ultrajaren públicamente la bandera, el escudo o el nombre de la patria y los que difamen, injurien o calumnien al Presidente de la República, Ministros de Estado, Senadores o Diputados, miembros de los Tribunales Superiores de Justicia, Contralor General de la República, Comandantes en Jefe de las Fuerzas Armadas, o General Director de Carabineros, sea que la difamación, la injuria o la calumnia se cometa con motivo o no del ejercicio de las funciones del ofendido». 
Respecto a Panamá, señala que tiene un marco legal que limita seriamente la libertad de expresión. Así, indica:

El Presidente Pérez Balladares ha dicho más de una vez que tiene la intención de cambiar la ley, pero hasta ahora no se ha hecho nada. Actualmente Panamá tiene un conjunto de leyes anacrónicas sobre la libertad de expresión. En lugar de actuar como una garantía efectiva de derechos, estas leyes se han convertido en una herramienta frecuentemente utilizada en manos de empleados gubernamentales que desean silenciar las críticas, restringiendo así la libertad de expresión y poniendo en peligro el debate público. Este uso de leyes obsoletas por parte de los empleados del gobierno ha creado una situación de acoso continuo y ha colocado un sitio virtual sobre los periodistas y la prensa en general. Dado que los periodistas a menudo desempeñan sus funciones en sectores de la sociedad que pueden afectar a las funciones de algunos empleados del gobierno, los periodistas ahora encuentran la amenaza de una acción judicial pendiente sobre ellos constantemente (Informe de la Oficina del Relator Especial para la Libertad de Expresión, 1998: volumen 3). ${ }^{9}$

Cabe señalar, por otra parte, que la Corte Interamericana ha razonado en reiteradas ocasiones sobre la base de consideraciones del Tribunal Europeo de Derechos Humanos, lo cual evidencia una mirada muchas veces compartida en esta materia. Así, ha referido a la interpretación del Tribunal Europeo sobre el artículo 10 inciso segundo del Convenio Europeo de Derechos Humanos, ${ }^{10}$ relativo a las restricciones a la libertad de expresión, en materias de debate electoral y otras de orden público, dejando a éstas un margen muy reducido, advirtiendo que para admitir una restricción no basta solo con que sea útil, razonable u oportuna (Sentencia de la Corte Interamericana de Derechos Humanos, Ivcher Bronstein contra Perú, párrafos centésimo quincuagésimo cuarto y centésimo quincuagésimo quinto, 6 de febrero de 2001), aplicando el criterio de la excepcionalidad de las restricciones del Tribunal Europeo, no solo a la información e ideas favorables, consideradas como inofensivas o indiferentes, sino también a las que ofenden, resultan chocantes o perturben (Sen-

9. Refiere, dentro de los principales pilares de este marco legal en Panamá: Decreto del Gabinete 251 de 1969 sobre la censura, capítulos 1 y 2 del Título 3 del Código Penal (artículos 172-180) sobre delitos contra el honor; las Leyes 11, 67 y 68 de 1978, sobre los medios de comunicación y el periodismo, comúnmente denominadas las «leyes de la mordaza»; disposiciones sobre el desacato derivado de la Constitución Política y el artículo 307 del Código Penal.

10. Artículo 10 inciso segundo del Convenio Europeo de Derechos Humanos: «[...] El ejercicio de estas libertades, que entrañan deberes y responsabilidades, podrá ser sometido a ciertas formalidades, condiciones, restricciones o sanciones, previstas por la ley, que constituyan medidas necesarias, en una sociedad democrática, para la seguridad nacional, la integridad territorial o la seguridad pública, la defensa del orden y la prevención del delito, la protección de la salud o de la moral, la protección de la reputación o de los derechos ajenos, para impedir la divulgación de informaciones confidenciales o para garantizar la autoridad y la imparcialidad del poder judicial». 
tencia de la Corte Interamericana de Derechos Humanos, Herrera Ulloa contra Costa Rica, párrafos centésimo vigésimo cuarto a centésimo vigésimo noveno, 2 de julio de 2004; Ricardo Canese contra Paraguay, serie C-111, párrafos nonagésimo séptimo y centésimo a centésimo tercero, 31 de agosto de 2004).

En lo que respecta a la censura (Carbonell, 2005: 12), el artículo 13 de la Convención Interamericana refiere expresamente a la prohibición de la censura previa, lo cual constituye una de las características principales de la protección de la libertad de expresión en el sistema interamericano. Implica un reconocimiento del peligro que acarrea la creación de mecanismos para decidir qué pueden escuchar, ver o leer las personas, peligro que no desaparece con la sola adopción de requisitos específicos que condicionen el ejercicio de la censura. Al decir de Grossman:

expresiones tales como «seguridad nacional», «moral» $\mathrm{O}$ «buenas costumbres» son fácilmente utilizables como pretextos para eliminar o limitar seriamente la libre expresión de ideas. Ciertamente, el peligro de abuso es aún mayor cuando los órganos encargados de ejercer la censura previa son de carácter nacional (Grossman, 2007: 178).

Ahora bien, para cumplir con el principio de legalidad, el ejercicio de la censura previa requiere la existencia de una ley que las autorice, de modo que los decretos u otras medidas administrativas, sin una ley previa que las regule, no resultan suficientes. El requisito de necesidad requiere que se evalúe la pertinencia de la medida, en cada caso concreto.

Como abordaré más adelante, en el caso «La última tentación de Cristo versus Chile» (Sentencia de la Corte Interamericana de Derechos Humanos, Olmedo Bustos y otros contra Chile «La última tentación de Cristo», párrafos septuagésimo primero a septuagésimo tercero, 5 de febrero de 2001), la Corte Interamericana consideró que un Estado es responsable internacionalmente cuando su legislación interna consagra normas que establecen la censura previa en la producción cinematográfica. En el caso Palamara Iribarne versus Chile (Sentencia de la Corte Interamericana de Derechos Humanos, Palamara Iribarne contra Chile, párrafo sexagésimo octavo, 22 de noviembre de 2005), señala la Corte que hay hipótesis en las cuales la censura previa constituye una violación radical tanto al derecho de cada persona de expresarse libremente como del derecho de todos a estar informados, y esto sucede cuando el poder público establece medios para impedir la libre circulación de información, ideas, opiniones o noticias. Ejemplos son la censura previa, el secuestro o la prohibición de publicaciones y, en general, todos aquellos procedimientos que condicionan la expresión o la difusión de información al control del Estado. 


\section{La libertad de expresión en el sistema europeo}

El Convenio Europeo, en el artículo 10, ${ }^{11}$ regula la garantía de la libertad de expresión. Esta norma, fundamento de la jurisprudencia del Tribunal Europeo de Derechos Humanos (TEDH) sobre las libertades de la comunicación, tiene por objeto la protección de la libertad de expresión y de información, sin injerencias de las autoridades y sin consideración de fronteras. Son numerosos los casos llevados ante el Tribunal de Estrasburgo en los que se ha invocado el artículo 10, lo cual le ha permitido la elaboración de una relevante doctrina sobre la materia.

El Tribunal ha consagrado a la libertad de expresión en un lugar eminente en el seno del conjunto de derechos y libertades por los que está encargado de velar. La primera vez que dictó una sentencia referida a esta garantía fue en el asunto Sunday Times (Sentencia del Tribunal Europeo de Derechos Humanos, serie A, número 3026 de abril de 1979), oportunidad en la que resolvió que se violó el artículo 10 del Convenio de Derechos Humanos, en razón de una intromisión de la autoridad que impedía publicar un artículo relativo a un medicamento.

Respecto al sentido y alcance de la libertad de expresión, en el asunto Handyside con Reino Unido (Tribunal Europeo de Derechos Humanos, 7 de diciembre de 1976) la erige como un presupuesto básico y componente esencial de la sociedad democrática, que se sostiene en el pluralismo, la tolerancia y en un comportamiento de apertura mental. En este sentido, afirmó que es indispensable para el funcionamiento de un estado democrático la existencia de una opinión pública libre y del pluralismo de opiniones, en tanto la libertad de expresión es una precondición esencial para las elecciones políticas y para el progreso de la democracia, sosteniendo inclusive que ello:

no se aplica solamente a las informaciones o ideas que se reciben favorablemente o se consideran inocuas o indiferentes, sino también a las que ofenden, hieren o molestan, porque así lo exigen el pluralismo y la mentalidad amplia propios de una sociedad democrática (Sentencia del Tribunal Europeo de Derechos Humanos, caso Handyside con Reino Unido, párrafo cuadragésimo noveno, 7 de diciembre de 1976).

11. Artículo 10 del Convenio Europeo: «Toda persona tiene derecho a la libertad de expresión. Este derecho comprende la libertad de opinión y la libertad de recibir o de comunicar informaciones o ideas sin que pueda haber injerencia de autoridades públicas y sin consideración de fronteras. El presente artículo no impide que los Estados sometan a las empresas de radiodifusión, de cinematografía o de televisión a un régimen de autorización previa. [...] El ejercicio de estas libertades, que entrañan deberes y responsabilidades, podrá ser sometido a ciertas formalidades, condiciones, restricciones o sanciones, previstas por la ley, que constituyan medidas necesarias, en una sociedad democrática, para la seguridad nacional, la integridad territorial o la seguridad pública, la defensa del orden y la prevención del delito, la protección de la salud o de la moral, la protección de la reputación o de los derechos ajenos, para impedir la divulgación de informaciones confidenciales o para garantizar la autoridad y la imparcialidad del poder judicial». 
A partir de este pronunciamiento, cada vez que el TEDH ha tenido que aplicar el artículo 10 del Convenio, la referencia a la libertad de expresión como fundamento de la democracia ha sido constante. Al decir de Teresa Freixes Sanjuán «desde esta perspectiva, el TEDH confiere a la libertad de expresión la connotación de garantía de la circulación de las informaciones que, en una sociedad democrática, constituyen la base de la acción política y proporcionan a los ciudadanos las informaciones necesarias para la creación de una opinión pública libre» (Freixes Sanjuán, 2003: 4).

Respecto al contenido de esta garantía fundamental, lo ha entendido de manera amplia, incluyendo diversas manifestaciones, tales como opiniones, informaciones, crítica política e ideológica en sentido amplio, manifestaciones artísticas y publicidad comercial garantizando su ejercicio libre de interferencias indebidas de la autoridad. Refiere también en sus pronunciamientos a los soportes técnicos, incluyendo a todo tipo, según los distintos medios de comunicación, como la prensa, radio, televisión, cinematografía, video, obra artística, fotografía y redes informáticas. Ahora bien, no utiliza los términos libertad de expresión y derecho a la información en forma indistinta, pues considera que la libertad de expresión comprende tanto la libertad de opinión como la libertad de información; así, en el asunto Sunday Times contra Reino Unido, tras señalar que la libertad de expresión es uno de los pilares fundamentales de las sociedades democráticas agrega que «a esta función de comunicación se añade el derecho del público de recibirla, derivando del derecho del público a recibir información la libertad del comunicador para emitirla» (Sentencia del Tribunal Europeo de Derechos Humanos, párrafo sexagésimo quinto, 26 de abril de 1979).

Con ello, hace hincapié en que se debe distinguir entre «hechos» $\mathrm{y}$ «juicios de valor». En el asunto Lingens contra Austria constata que «mientras que la realidad de los primeros puede probarse, los segundos no son susceptibles de prueba» (Sentencia del Tribunal Europeo de Derechos Humanos, serie A-103, párrafo cuadragésimo primero, 8 de julio de 1986); a partir de esta sentencia los tribunales austríacos aplican el Código Penal teniendo en cuenta la doctrina del TEDH.

El Tribunal admite restrictivamente ciertas limitaciones a la libertad de expresión. El mismo artículo 10 inciso segundo del Convenio las considera, cuando señala que el ejercicio de estas libertades podrá ser sometido a ciertas restricciones, previstas por la ley, que constituyan medidas necesarias para la seguridad nacional, la integridad territorial o la seguridad pública, la defensa del orden y la prevención del delito, la protección de la salud o de la moral, la protección de la reputación o de los derechos ajenos, para impedir la divulgación de informaciones confidenciales o para garantizar la autoridad y la imparcialidad del poder judicial. Al decir de Jean Paul (Costa, 2001: 2), cuando el Tribunal ejerce un control de proporcionalidad utiliza con frecuencia la siguiente expresión: «la injerencia debe responder a una necesidad social imperiosa», lo que demuestra que es particularmente estricto a este respecto.

La jurisprudencia del Tribunal ha sido severa con la libertad de expresión cuando 
en su ejercicio ha considerado que afecta a los derechos de otro, en especial tratándose de los sentimientos religiosos de las personas; así ocurre, como analizaré más adelante, en asunto Otto Preminger Institut versus Austria (Sentencia del Tribunal Europeo de Derechos Humanos, 20 de septiembre de 1994), a propósito de la difusión de una película basada en la obra de Panizza, el Concilio del Amor; del mismo modo, por una película de video calificada como blasfema, asunto Wingrove versus Reino Unido (Sentencia del Tribunal Europeo de Derechos Humanos, 25 de noviembre de 1996); así mismo, cuando la libertad de expresión atenta contra la protección de la moral, asunto Muller versus Suiza (Sentencia del Tribunal Europeo de Derechos Humanos, 24 de mayo de 1988), a propósito de las medidas tomadas contra el autor de lienzos considerados obscenos. En otras ocasiones ha arribado a una conclusión en sentido inverso, como cuando condenó a Irlanda por violación del artículo 10, en razón de haber prohibido, en nombre de la moral, la difusión de informaciones sobre las posibilidades de abortar en el extranjero, siendo el aborto ilegal en dicho país (Sentencia del Tribunal Europeo de Derechos Humanos, caso Open Door \& Dublin Well Woman con Irlanda, 29 de octubre de 1992; cf. Freixes Sanjuán, 2003: 6).

A este respecto, adquiere especial relevancia la teoría del «Margen de Apreciación», desarrollada por el Tribunal a partir del asunto Régimen de la Lengua en la Educación en Bélgica (Sentencia del Tribunal Europeo de Derechos Humanos, serie A, volumen 6, 23 de julio de 1968), por cuya virtud entiende que son los Estados quienes pueden y deben legislar sobre la interposición y la configuración de los límites concretos de una injerencia.

El TEDH define el margen de apreciación como el terreno discrecional que se ofrece a las sociedades democráticas, para decidir sobre la extensión de una injerencia, de manera que serán las autoridades internas quienes resuelvan sobre su interposición y configuración; consecuentemente, reserva a los Estados un margen de apreciación, que se concede tanto al legislador nacional como a los órganos, especialmente a los judiciales, llamados a interpretar y aplicar las leyes en vigor.

El Tribunal ha adoptado esta doctrina con la finalidad de otorgar deferencia al criterio de los Estados en la protección de los derechos del Convenio Europeo de Derechos Humanos. Ha expresado a este respecto diversas razones que justifican el criterio del margen de apreciación de los Estados. Así, observa que el sistema de protección de derechos humanos en Europa es fruto de una división del trabajo entre los Estados y el TEDH. Los Estados son los responsables primarios de esta protección y el Tribunal de Estrasburgo solo interviene de forma subsidiaria, por vía contenciosa, y una vez que se han agotado los recursos judiciales internos. Por otra parte, en ámbitos tan sensibles como la moralidad o la religión, no hay consenso entre los Estados en los modos de regulación y las autoridades nacionales, al estar en contacto directo con las fuerzas vitales de su país, se hallan mejor situadas para conocer su coyuntura social y decidir la forma adecuada de gestionar situaciones conflictivas. 
No obstante, según el propio TEDH, este margen es limitado, sujeto a supervisión, y variará en función de lo sensible que sea la cuestión a decidir, el tipo de derecho en juego, el carácter más o menos objetivable de los intereses legítimos perseguidos por el Estado y la evolución del consenso europeo en la materia (Sentencia del Tribunal Europeo de Derechos Humanos, caso Handyside con Reino Unido, párrafos cuadragésimo octavo y cuadragésimo noveno, 7 de diciembre de 1976). Aclara al respecto que dicho margen será siempre objeto de una estricta supervisión europea, pudiendo ser controlado por el propio TEDH, quien es finalmente el encargado de velar por que las medidas estatales se ajusten y estén conforme al Convenio Europeo.

Al decir de Fernández Segado, la amplitud de ese poder nacional de apreciación no será siempre la misma. Dicho ámbito variará según la mayor o menor objetividad del concepto jurídico de que se trate, de manera que, si esa objetividad disminuye, aumenta el margen de apreciación de las autoridades nacionales. Por consiguiente, advierte el autor, «la tarea del Tribunal no consiste en sustituir a las jurisdicciones internas competentes, sino apreciar, desde la perspectiva del artículo 10, las decisiones dictadas en el ejercicio de su poder de apreciación».

$\mathrm{Al}$ respecto, señala:

el Tribunal debe asegurarse que la injerencia sea necesaria teniendo en cuenta los hechos y circunstancias del caso, por lo que el control no puede circunscribirse a un examen aislado de las decisiones de las autoridades nacionales. En definitiva, incumbe al órgano jurisdiccional europeo la decisión última acerca de si la injerencia impugnada ante él se funda en una necesidad social imperiosa, si es proporcional al fin legítimo perseguido y si los motivos dados por las autoridades nacionales para justificarla son pertinentes y suficientes (Fernández Segado, 1990: 117-119).

Puede afirmarse que, en general, el Tribunal ha reconocido un margen de apreciación amplio a los Estados cuando limitan la libertad de expresión por motivos de seguridad nacional o de orden público. En el asunto Fressoz y Roire contra Francia (Sentencia del Tribunal Europeo de Derechos Humanos, 21 de enero de 1999), el TEDH reiteró, como principio general,

la necesidad de que cualquier injerencia en la libertad de expresión ha de ser establecida de modo concluyente [...] Las autoridades nacionales gozan de un cierto margen de apreciación en su consideración sobre si se da una «necesidad social» para la restricción [...]. El margen nacional de apreciación se encuentra sujeto al interés de una sociedad democrática en mantener una prensa libre (Sentencia del Tribunal Europeo de Derechos Humanos, caso Fressoz y Roire contra Francia, párrafo cuadragésimo quinto, 21 de enero de 1999).

Como referiré más adelante, en los asuntos Wingrove contra Reino Unido (Sentencia del Tribunal Europeo de Derechos Humanos, 25 de noviembre de 1996) y Otto 
Preminger Institut versus Austria (Sentencia del Tribunal Europeo de Derechos Humanos, 20 de septiembre de 1994), funda sus decisiones en la teoría del margen de apreciación de los Estados para justificar las injerencias de los poderes públicos en defensa de las creencias religiosas.

\section{El respeto a las creencias religiosas}

La libertad de religión supone la capacidad de toda persona para autodeterminarse en su comportamiento, conforme a sus propias convicciones y creencias, particularmente en el plano religioso. La religión conlleva la aceptación de las costumbres, prácticas, ritos y otras manifestaciones, propias de cada una de éstas (Espinoza Ariza, 2015: 89, 94). Existe una compleja interrelación entre las libertades de expresión y religiosa, con constantes confrontaciones entre ambas, siendo difícil analizarlas sin vincularlas.

En el sistema europeo, el artículo 9 del Convenio de Derechos Humanos ${ }^{12}$ asegura el derecho de cualquier individuo a la libertad de pensamiento, de conciencia y de religión. Según el propio artículo, esta libertad implica además el poder comunicar y manifestar la religión o creencias libremente.

Por su parte, en el sistema interamericano la Convención Interamericana regula en términos similares la libertad de conciencia y de religión, asegurando también, en el artículo $12,{ }^{13}$ que ésta implica la libertad de cada persona para profesar y divulgar su religión o sus creencias, individual o colectivamente, tanto en público como en privado.

12. Artículo 9 del Convenio de Derechos Humanos, libertad de pensamiento, de conciencia y de religión: «1. Toda persona tiene derecho a la libertad de pensamiento, de conciencia y de religión; este derecho implica la libertad de cambiar de religión o de convicciones, así como la libertad de manifestar su religión o sus convicciones individual o colectivamente, en público o en privado, por medio del culto, la enseñanza, las prácticas y la observancia de los ritos. [...] 2. La libertad de manifestar su religión o sus convicciones no puede ser objeto de más restricciones que las que, previstas por la ley, constituyan medidas necesarias, en una sociedad democrática, para la seguridad pública, la protección del orden, de la salud o de la moral públicas, o la protección de los derechos o las libertades de los demás».

13. Artículo 12 de la Convención Interamericana de Derechos Humanos, libertad de conciencia y de religión: «1. Toda persona tiene derecho a la libertad de conciencia y de religión. Este derecho implica la libertad de conservar su religión o sus creencias, o de cambiar de religión o de creencias, así como la libertad de profesar y divulgar su religión o sus creencias, individual o colectivamente, tanto en público como en privado. [...] 2. Nadie puede ser objeto de medidas restrictivas que puedan menoscabar la libertad de conservar su religión o sus creencias o de cambiar de religión o de creencias. [...] 3. La libertad de manifestar la propia religión y las propias creencias está sujeta únicamente a las limitaciones prescritas por la ley y que sean necesarias para proteger la seguridad, el orden, la salud o la moral públicos o los derechos o libertades de los demás. [...] 4. Los padres, y en su caso los tutores, tienen derecho a que sus hijos o pupilos reciban la educación religiosa y moral que esté de acuerdo con sus propias convicciones». 
Con esta conceptualización, como se precisa en Human Rights Watch (1998: 32) se mezclan la libertad de conciencia y religión con la libertad de manifestarlas, y es precisamente en este punto donde entra en juego la libertad de expresión y ambas se entrecruzan.

Tanto el sistema interamericano como el europeo consignan la restrictividad de las limitaciones a la libertad religiosa y consagran la reserva legal de las mismas, esto es, que solo proceden las que estén prescritas en la ley y que tengan por objeto precaver la seguridad y la moral pública, el orden, la salud, o la protección de los derechos o las libertades de los demás.

A partir de los límites previstos en el inciso segundo del artículo 10 del Convenio Europeo de Derechos Humanos, en relación con la protección de la moral y la de los derechos y libertades de terceros, el Tribunal Europeo ha considerado que el respeto a las creencias religiosas puede también llegar a constituir un límite a la libertad de expresión.

La primera sentencia del Tribunal Europeo que se adentra en el tema de la libertad religiosa como elemento delimitador de la libertad de expresión, corresponde al asunto Instituto Otto Preminger contra Austria (Sentencia del Tribunal Europeo de Derechos Humanos, 20 de septiembre de 1994); como referiré más adelante, en este asunto, tras afirmar que la libertad de religión exige que se tolere la crítica, el Tribunal considera que dicha libertad no da cobertura a los insultos proferidos en una película, incluso si no existe, un concepto europeo general sobre el significado de la religión en la sociedad. Es el margen de apreciación de los Estados el que fundamenta esta posición para justificar las injerencias de los poderes públicos (secuestro y confiscación de una película) en defensa de las creencias religiosas. Algo similar ocurrió en el asunto Wingrove contra Reino Unido (Sentencia del Tribunal Europeo de Derechos Humanos, 25 de noviembre de 1996), en que también se ampara en la teoría del margen de apreciación de los Estados, para avalar la existencia del delito de blasfemia y, subsiguientemente, la no autorización de un video.

En el sistema interamericano, los términos del artículo 27 de la Convención Interamericana de Derechos Humanos, ${ }^{14}$ que regula los derechos que no pueden suspen-

14. Artículo 27, Convención Interamericana de Derechos Humanos. Suspensión de Garantías: «1. En caso de guerra, de peligro público o de otra emergencia que amenace la independencia o seguridad del Estado parte, éste podrá adoptar disposiciones que, en la medida y por el tiempo estrictamente limitados a las exigencias de la situación, suspendan las obligaciones contraídas en virtud de esta Convención, siempre que tales disposiciones no sean incompatibles con las demás obligaciones que les impone el derecho internacional y no entrañen discriminación alguna fundada en motivos de raza, color, sexo, idioma, religión u origen social. [...] 2. La disposición precedente no autoriza la suspensión de los derechos determinados en los siguientes artículos: 3 (Derecho al Reconocimiento de la Personalidad Jurídica); 4 (Derecho a la Vida); 5 (Derecho a la Integridad Personal); 6 (Prohibición de la Esclavitud y Servidumbre); 9 (Principio de Legalidad y de Retroactividad); 12 (Libertad de Conciencia y de Religión); 17 (Pro- 
derse, en los que incluye solo a la libertad de expresión y no a la religiosa, han dado pie a algunos para afirmar que en este sistema la libertad de expresión goza de mayor protección y tiene preponderancia por sobre la libertad de religión (Freixes Sanjuán, 2003: 3). «En el caso de La última tentación de Cristo», la Corte Interamericana estableció importantes criterios para fijar el sentido y alcance de esta disposición, y señaló que según el artículo 12 de la Convención, el derecho a la libertad de conciencia y de religión permite que las personas conserven, cambien, profesen y divulguen su religión o creencias, constituyendo este derecho uno de los cimientos de la sociedad democrática y un elemento trascendental en la protección de las convicciones de los creyentes y en su forma de vida (Sentencia de la Corte Interamericana de Derechos Humanos, Olmedo Bustos y otros contra Chile «La Última Tentación de Cristo», párrafo septuagésimo noveno, 5 de febrero de 2001).

\section{La última tentación de Cristo}

El 15 de enero de 1999 la Comisión Interamericana sometió ante la Corte Interamericana de Derechos Humanos una demanda contra la República de Chile, a fin de resolver si hubo o no violación de la libertad de expresión por la censura judicial impuesta a la exhibición cinematográfica de la película La última tentación de Cristo.

En efecto, la sentencia de la Corte de Apelaciones de Santiago, del 20 de enero de 1997, rol 4.079-96, confirmada por la Corte Suprema de Chile el 17 de junio de 1997, estableció que en la película La última tentación de Cristo, la imagen de Cristo es deformada y minimizada al máximo, por lo que el asunto plantea resolver si en aras de la libertad de expresión es posible afectar las creencias serias de una gran cantidad de personas. Señala la Corte que la Constitución busca proteger al hombre, a sus instituciones y a sus creencias, pues éstos son los elementos más centrales de la convivencia y la pertenencia de los seres humanos a un mundo pluralista. Pluralismo no es enlodar y destruir las creencias de otros, sean éstos mayorías o minorías, sino asumirlas como un aporte a la interacción de la sociedad en cuya base está el respeto a la esencia y al contexto de las ideas del otro. Si se descuidan los valores de una Nación o se dejan manosear, advierte, como se manosea y deforma la imagen de Cristo, ésta peligra, pues los valores en que se sustenta se ignoran. Cuidar la necesidad de información o de expresión tiene una estrechísima relación con la veracidad de los hechos y por eso deja de ser información o expresión la deformación histórica de un hecho o de una

tección a la Familia); 18 (Derecho al Nombre); 19 (Derechos del Niño); 20 (Derecho a la Nacionalidad), y 23 (Derechos Políticos), ni de las garantías judiciales indispensables para la protección de tales derechos. [... 3. Todo Estado parte que haga uso del derecho de suspensión deberá informar inmediatamente a los demás Estados Partes en la presente Convención, por conducto del Secretario General de la Organización de los Estados Americanos, de las disposiciones cuya aplicación haya suspendido, de los motivos que hayan suscitado la suspensión y de la fecha en que haya dado por terminada tal suspensión.» 
persona. Por esto es que los sentenciadores creen que el derecho de emitir opinión es el derecho a calificar una realidad, pero nunca el deformarla haciéndola pasar por otra. Con base en estas consideraciones es que dicha Corte de Apelaciones, en fallo confirmado por la Corte Suprema de Justicia, prohibió la exhibición de la película $\mathrm{La}$ última tentación de Cristo.

Cabe señalar que, a la fecha de la ocurrencia de los hechos, la Constitución Política de Chile establecía en el artículo 19 número $12,{ }^{15}$ un sistema de censura para la exhibición y publicidad de la producción cinematográfica.

Sometido el asunto al conocimiento de la Corte Interamericana de Derechos $\mathrm{Hu}$ manos, ésta resolvió, el 5 de febrero de 2001, que el Estado de Chile era responsable por vulneración de la libertad de pensamiento y de expresión, consagrado en el artículo 13 de la Convención Interamericana sobre Derechos Humanos. Asimismo, declara que el Estado no violó el derecho a la libertad de conciencia y de religión consagrado en el artículo 12 de la Convención. Este caso, además de ser el primer pronunciamiento de la Corte Interamericana sobre la libertad de expresión en el siglo XX, resalta la importancia que tiene para la sociedad y el individuo, la pluralidad de creencias y opiniones que deben existir sobre un tema específico. Toda persona puede escoger libremente las películas que considere de su interés y no puede verse restringido en sus decisiones personales porque sectores de la sociedad consideren que sus creencias puedan verse amenazadas con determinada clase de películas.

En lo que respecta a la libertad de pensamiento y de expresión, señala (párrafo sexagésimo tercero) que conforme a lo consignado en el artículo 13 de la Convención, toda persona tiene derecho a ésta, comprendiendo también la libertad de buscar, recibir y difundir informaciones e ideas de toda índole, sin consideración de fronteras, ya sea oralmente, por escrito o en forma impresa o artística, o por cualquier otro

15. El texto original de la Constitución Política de Chile de 1980, establecía: «Artículo 19.- La Constitución asegura a todas las personas: 12.- La libertad de emitir opinión y la de informar, sin censura previa, en cualquier forma y por cualquier medio, sin perjuicio de responder de los delitos y abusos que se cometan en el ejercicio de estas libertades, en conformidad a la ley, la que deberá ser de quórum calificado. [...] La ley en ningún caso podrá establecer monopolio estatal sobre los medios de comunicación social. [...] Toda persona natural o jurídica ofendida o injustamente aludida por algún medio de comunicación social, tiene derecho a que su declaración o rectificación sea gratuitamente difundida, en las condiciones que la ley determine, por el medio de comunicación social en que esa información hubiera sido emitida. [...] Toda persona natural o jurídica tiene el derecho de fundar, editar y mantener diarios, revistas y periódicos, en las condiciones que señale la ley. [...] El Estado, aquellas universidades y demás personas o entidades que la ley determine, podrán establecer, operar y mantener estaciones de televisión. [...] Habrá un Consejo Nacional de Radio y Televisión, autónomo y con personalidad jurídica, encargado de velar por el correcto funcionamiento de estos medios de comunicación. Una ley de quórum calificado señalará la organización y demás funciones y atribuciones del referido Consejo. [...] La ley establecerá un sistema de censura para la exhibición y publicidad de la producción cinematográfica y fijará las normas generales que regirán la expresión pública de otras actividades artísticas». 
procedimiento de su elección. La Convención prohíbe cualquier forma de medida preventiva al ejercicio de la libertad de expresión, y dispone en el inciso segundo del artículo 13 que este derecho no puede estar sujeto a censura previa sin responsabilidad ulterior. Las excepciones deben estar expresamente fijadas por la ley y ser necesarias para asegurar:

- el respeto a los derechos o a la reputación de los demás, o

- la protección de la seguridad nacional, el orden público o la salud o la moral públicas.

No puede restringirse el derecho de expresión por medios indirectos, tales como el abuso de controles oficiales o particulares de papel para periódicos, de frecuencias radioeléctricas, o de enseres y aparatos usados en la difusión de información o por cualesquiera otros medios encaminados a impedir la comunicación y la circulación de ideas y opiniones.

Respecto al contenido del derecho a la libertad de pensamiento y de expresión, precisa que quienes están bajo la protección de la Convención tienen no solo el derecho y la libertad de expresar su propio pensamiento, sino también el derecho y la libertad de buscar, recibir y difundir informaciones e ideas de toda índole. Ello conlleva a una doble dimensión de la libertad de expresión, tanto individual como social, esto es, requiere, por un lado, que nadie sea arbitrariamente menoscabado o impedido de manifestar su propio pensamiento, y por otro, implica también un derecho colectivo a recibir cualquier información y a conocer la expresión del pensamiento ajeno. La dimensión individual implica que la libertad de expresión no se agota en el reconocimiento teórico del derecho a hablar o escribir, sino que comprende además, inseparablemente, el derecho a utilizar cualquier medio apropiado para difundir el pensamiento, de modo que la expresión y la difusión del pensamiento y de la información son indivisibles, por lo que una restricción de las posibilidades de divulgación representa directamente, y en la misma medida, un límite al derecho de expresarse libremente (Sentencia de la Corte Interamericana de Derechos Humanos, Olmedo Bustos y otros contra Chile «La última tentación de Cristo», párrafo sexagésimo cuarto, 5 de febrero de 2001).

La dimensión social del derecho implica que la libertad de expresión es un medio para el intercambio de ideas e informaciones entre las personas, por lo que comprende su derecho a tratar de comunicar a otras sus puntos de vista, así como el derecho de todas a conocer opiniones, relatos y noticias. Ambas dimensiones, a juicio de la Corte, poseen igual importancia y deben ser por ende garantizadas para dar efectividad total al derecho a la libertad de pensamiento y de expresión en los términos en que se encuentran consignados en el artículo 13 de la Convención (Sentencia de la Corte Interamericana de Derechos Humanos, Olmedo Bustos y otros contra Chile «La última tentación de Cristo», párrafo sexagésimo sexto, 5 de febrero de 2001). 
La Corte realza la importancia de la libertad de expresión para la construcción de sociedades democráticas, para lo cual refiere al criterio del Tribunal Europeo (Sentencia de la Corte Interamericana de Derechos Humanos, Olmedo Bustos y otros contra Chile «La última tentación de Cristo», párrafo sexagésimo noveno, 5 de febrero de 2001), que postula que la libertad de expresión constituye uno de los fundamentos esenciales de tal sociedad, lo que es válido no solo para las informaciones o ideas que son favorablemente recibidas o consideradas como inofensivas o indiferentes, sino también para aquellas que chocan, inquietan u ofenden al Estado o a una fracción cualquiera de la población, lo cual significa que toda restricción impuesta en la materia debe ser proporcionada al fin legítimo que se persigue, y que cualquiera que ejerce su libertad de expresión asume deberes y responsabilidades. Ahora bien, el artículo 13 de la Convención contempla en su inciso cuarto una excepción a la prohibición de censura previa, ya que la permite en el caso de los espectáculos públicos, pero únicamente con el fin de regular el acceso a ellos, en aras de la protección moral, de la infancia y la adolescencia. En todos los demás casos, cualquier medida preventiva implica el menoscabo a esta garantía.

Aclara que en el caso en comento se probó que en Chile existe un sistema de censura previa para la exhibición y publicidad de la producción cinematográfica, y que el Consejo de Calificación Cinematográfica prohibió la exhibición de la película $\mathrm{La}$ última tentación de Cristo. La Corte entiende que la responsabilidad internacional del Estado puede generarse por actos u omisiones de cualquiera de sus órganos que violen la Convención Americana. En el presente caso ésta se generó en virtud de que el artículo 19 número 12 de la Constitución establece la censura previa en la producción cinematográfica y, por lo tanto, determina los actos de los Poderes Ejecutivo, Legislativo y Judicial (Sentencia de la Corte Interamericana de Derechos Humanos, Olmedo Bustos y otros contra Chile «La última tentación de Cristo», párrafo septuagésimo primero, 5 de febrero de 2001).

En base a todas las consideraciones precedentes, la Corte declara que el Estado de Chile violó el derecho a la libertad de pensamiento y de expresión consagrado en el artículo 13 de la Convención Americana, en perjuicio de los requirentes (Sentencia de la Corte Interamericana de Derechos Humanos, Olmedo Bustos y otros contra Chile «La última tentación de Cristo», párrafo septuagésimo tercero, 5 de febrero de 2001)

En lo que concierne a la libertad de conciencia y de religión, consignada en el artículo 12 de la Convención, la Corte ha entendido que esta libertad implica que toda persona tiene derecho a esta garantía, lo que implica la libertad de conservar o de cambiar su religión o sus creencias, así como la libertad de profesarlas y divulgarlas, individual o colectivamente, tanto en público como en privado, sin que puedan ser objeto de medidas restrictivas que menoscaben dichos derechos. La libertad de manifestar la propia religión y las propias creencias está sujeta únicamente a las limitaciones prescritas por la ley y que sean necesarias para proteger la seguridad, el orden, 
la salud o la moral públicos o los derechos o libertades de los demás. Los padres, y en su caso los tutores, tienen derecho a que sus hijos o pupilos reciban la educación religiosa y moral que esté de acuerdo con sus propias convicciones. También la erige a como uno de los cimientos de la sociedad democrática; señala que constituye un elemento esencial la protección de las convicciones de los creyentes y en su forma de vida (Sentencia de la Corte Interamericana de Derechos Humanos, Olmedo Bustos y otros contra Chile «La última tentación de Cristo», párrafo septuagésimo sexto, 5 de febrero de 2001).

Entiende que en el caso, la prohibición de la exhibición de la película «La última tentación de Cristo» no privó o menoscabó a ninguna persona su derecho de conservar, cambiar, profesar o divulgar, con absoluta libertad, su religión o sus creencias, y que no existe prueba alguna que acredite la violación de ninguna de las libertades consagradas en el artículo 12 de la Convención, por lo que la Corte concluye que el Estado no violó el derecho a la libertad de conciencia y de religión consagrado en el artículo 12 de la Convención Interamericana. La Corte concluye que el Estado de Chile incumplió los deberes generales de respetar y garantizar los derechos protegidos por la Convención y de adecuar el ordenamiento jurídico interno a las disposiciones de ésta, consagrados en los artículos 1.1 y 2 de la Convención Americana sobre Derechos Humanos (Sentencia de la Corte Interamericana de Derechos Humanos, Olmedo Bustos y otros contra Chile «La última tentación de Cristo», párrafo septuagésimo noveno, 5 de febrero de 2001).

El Estado de Chile cumplió lo dispuesto por la Corte Interamericana a través de la reforma constitucional introducida por la Ley 19.742 de 25 de agosto de 2001 y con la dictación de la Ley 19.846, de 4 de enero de 2003, sobre Calificación de Producción Cinematográfica; ello deja de manifiesto la influencia en el derecho interno de los pronunciamientos de organismos internacionales, que cumplen, por ende, una labor relevante en el establecimiento del contenido y alcances de los derechos fundamentales, así como en la protección de los mismos.

\section{Otto Preminger-Institud contra Austria}

Mediante sentencia dictada en Estrasburgo el 20 de septiembre de 1994, en el caso Otto Preminger-Institut contra Austria, el TEDH resuelve que no hubo violación a la libertad de expresión, por el hecho de que diversas sentencias judiciales austriacas hubieran ordenado la retirada y después incautación de la película, «Das Liebekonzil», de Werner Schroeter.

En efecto, el 13 de mayo de 1985, la asociación austriaca Otto Preminger-Institut für audiovisuelle Mediengestaltung (OPI) anunció en periódicos y carteles la proyección de la película «Das Liebekoonzil» (El Concilio de amor), de Wemer Schroeter. La película estaba basada en la obra de Oskar Panizza, de 1885, el que ya entonces había 
sido condenado a prisión por un delito de blasfemia. En ella se caricaturizaban conceptos de la fe cristiana, se representaba a Dios como un idiota senil e impotente, a Jesucristo como a un hijo malcriado y cretino, a María como a una desvergonzada sin escrúpulos, se ridiculizaba la eucaristía y se representaban escenas de insinuaciones eróticas entre María y el Diablo.

Tras una demanda de la diócesis de Innsbruck de la Iglesia Católica Romana, el fiscal inició acciones penales en contra del gerente de la asociación, con motivo de sospecha de tentativa de «denigración de preceptos religiosos», sancionada por el artículo 188 del Código Penal austriaco; se ordenó así la retirada de la película, que, por tanto, no pudo ser exhibida al público. El gerente de la asociación interpuso un recurso contra la orden de retirada, que fue rechazado por el Tribunal de Apelación de Innsbruck, que señaló que la libertad artística estaba limitada necesariamente por los derechos de los demás a la libertad de religión y por el deber del Estado de garantizar una sociedad cimentada sobre los valores del orden y de la tolerancia. Las susodichas acciones penales fueron archivadas. El procedimiento siguió su curso bajo la forma de un objektives Verfahren, es decir, un procedimiento que no procura la condena de un individuo, sino la incautación de una película, en virtud del artículo 33 de la Ley sobre los medios de comunicación. El 10 de octubre de 1986 el tribunal regional de Innsbruck ordenó la incautación, juzgando que la gravedad del ataque a los sentimientos religiosos causada por la actividad provocadora de la película prevalecía sobre la libertad artística garantizada por la Constitución austriaca. La asociación Otto Preminger Institut denunció a Austria ante el TEDH por considerar que el secuestro del film constituía una violación de la libertad de expresión garantizada en el artículo 10 del Convenio Europeo de Derechos Humanos.

El TEDH entiende que tanto la retirada de la película como su incautación constituyen injerencias en el ejercicio del derecho a la libertad de expresión de la OPI, pero que dichas injerencias estaban previstas por la ley; OPI lo niega y sostiene que el artículo 188 del Código Penal austriaco ha sido aplicado de forma incorrecta. El Tribunal recuerda que incumbe en primer lugar a las autoridades nacionales, sobre todo a los juzgados y tribunales, interpretar y aplicar el derecho interno, y concluye que la normativa austriaca que regula la materia fue aplicada de manera correcta (Sentencia del Tribunal Europeo de Derechos Humanos, caso Otto Preminger Institut con Austria, párrafos cuadragésimo cuarto a cuadragésimo octavo, 20 de septiembre de 1994).

En lo relativo a la libertad de conciencia y de religión, consagrada en el artículo 9 del Convenio, la erige como uno de los pilares de una sociedad democrática, y advierte en tal sentido que sea que se pertenezca a una mayoría o a una minoría religiosa, se debe tolerar y aceptar el rechazo, por parte de los demás, de sus creencias religiosas e incluso la difusión por otros de doctrinas hostiles a su fe. Sin embargo, la manera en que las creencias y las doctrinas religiosas son objeto de ataque o de negación es una cuestión que puede comprometer la responsabilidad del Estado, en tanto éste 
debe garantizar a las personas el ejercicio pacífico de sus creencias. Considera que la libertad de expresión no da cobertura a los insultos proferidos en una película, incluso si no existe un concepto europeo general sobre el significado de la religión en la sociedad (Sentencia del Tribunal Europeo de Derechos Humanos, caso Otto Preminger Institut con Austria, párrafo cuadragésimo séptimo,20 de septiembre de 1994).

Advierte que quien ejerza los derechos y libertades consagrados en el artículo 10, asume a la vez ciertas responsabilidades, entre ellas - en el contexto de las opiniones y de las creencias religiosas - puede legítimamente estar comprendida una obligación de evitar, en la medida de lo posible, expresiones que de manera gratuita sean ofensivas para los demás y constituyan un ataque a sus derechos. De ello se deriva que en principio se puede juzgar necesario en algunas sociedades democráticas sancionar, pero también prevenir, ataques injuriosos contra objetos de veneración religiosa, teniendo en cuenta siempre que cualquier "formalidad», «condición», «restricción» o, «sanción», debe ser impuesta en proporción al fin legítimo perseguido. Ahora bien, como no es posible distinguir en Europa una concepción uniforme del significado de la religión dentro de la sociedad, y así, concepciones semejantes pueden variar incluso dentro de un solo país, señala que las autoridades nacionales deben disponer de un cierto margen de apreciación para determinar la existencia y la extensión de la necesidad de una injerencia semejante, margen que en todo caso no es ilimitado. A la vista de la importancia de las libertades en juego, la necesidad de cualquier restricción debe ser establecida de manera convincente. Destaca que aunque en este caso el acceso al cine para ver la película objeto del litigio estuviese sometido al pago de un derecho de entrada y a unas condiciones de edad, la película fue objeto de una muy amplia publicidad. El público tenía conocimiento suficiente sobre la temática y sobre sus líneas, por lo que la proyección prevista podría considerarse constitutiva de una expresión lo suficientemente «pública» para ser ofensiva (Sentencia del Tribunal Europeo de Derechos Humanos, caso Otto Preminger Institut con Austria, párrafo cuadragésimo noveno, 20 de septiembre de 1994). Entiende que las decisiones de las jurisdicciones austriacas tuvieron debidamente en cuenta la libertad de expresión artística, por lo que funda la legitimidad de la medida en el debido respeto a las creencias religiosas ajenas, entendiendo que éstas constituyen un límite a la libertad artística. Señala el Tribunal que no puede obviar el hecho de que la religión católica romana es la de la inmensa mayoría de los tiroleses. Al retirar la película, las autoridades austriacas actuaron para proteger la paz religiosa en esta región y para impedir que algunos se sintieran atacados en sus sentimientos religiosos de manera injustificada y ofensiva. Argumenta que es competencia en primer lugar de las autoridades nacionales, mejor situadas que el juez internacional, la evaluación de la necesidad de semejantes medidas a la luz de la situación existente en el plano local en una época concreta.

En aras de lo razonado, y teniendo en cuenta todas las circunstancias del caso concreto, el Tribunal estimó que las autoridades austriacas no podían ser reprochadas de 
haberse excedido en el margen de apreciación al respecto. Así pues, no considera que los jueces austriacos hayan aplicado incorrectamente la ley penal, pues el fin perseguido era legítimo, toda vez que la medida trataba de proteger los derechos de terceros, en este caso, el respeto a sus creencias religiosas; reitera en tal sentido su doctrina sobre la moral como límite a la libertad de expresión. Centrado en el secuestro de la película, el Tribunal apreció la existencia de un bien social perentorio, la paz y respeto entre creencias religiosas y el orden público. El Tribunal consideró que se había dado gran publicidad, con precisas referencias a su contenido, de manera que había un público conocimiento de su temática, una publicidad suficiente como para convenir en que es capaz de producir ofensas por sí misma. Por todas estas razones, el Tribunal Europeo consideró que los jueces austriacos no violaron el artículo 10 del Convenio. Estas mismas razones se aplicaron a la confiscación de la cinta cinematográfica subsiguiente al secuestro (Sentencia del Tribunal Europeo de Derechos Humanos, caso Otto Preminger Institut con Austria, párrafo quincuagésimo sexto, 20 de septiembre de 1994).

Por ende, y pese a que la incautación de la película hizo imposible su proyección de manera permanente en cualquier sitio dentro de Austria, considera que los medios utilizados no eran desproporcionados respecto del fin legítimo perseguido y que, en consecuencia, las autoridades nacionales no se excedieron en su margen de apreciación a este respecto y dictaminó que el respeto a los sentimientos religiosos se incluye dentro de la «protección de los derechos ajenos» que hace mención en el segundo apartado de dicho artículo. Nuevamente es el margen de apreciación de los Estados el que sirve de fundamento a la posición del Tribunal Europeo para justificar las injerencias de los poderes públicos (secuestro y confiscación de una película) en defensa de las creencias religiosas. Un Estado, advierte, puede legítimamente estimar necesario adoptar medidas encaminadas a reprimir ciertas formas de comportamiento, incluida la comunicación de informaciones e ideas consideradas incompatibles con el respeto a la libertad de conciencia y de religión de los demás. Señala que se puede legítimamente considerar que el respeto a los sentimientos religiosos de los creyentes, tal y como está garantizado en el artículo 9 , ha sido violado por representaciones provocadoras de objetos de culto religioso. Entiende que las medidas objeto del litigio procuraban proteger el derecho de los ciudadanos a no ser insultados en sus sentimientos religiosos, por lo que perseguían un fin legítimo al amparo del artículo 10.2, a saber, «la protección de los derechos de los demás» (Sentencia del Tribunal Europeo de Derechos Humanos, caso Otto Preminger Institut con Austria, párrafos quincuagésimo séptimo y quincuagésimo octavo, 20 de septiembre de 1994).

\section{Wingrove contra Reino Unido}

En 1989, el señor Nigel Wingrove dirige y escribe el guion de un video titulado Visiones del éxtasis, que explora la vida y escritos de Santa Teresa de Ávila, una monja 
carmelita del siglo XVI. El Comité Británico de Clasificación Cinematográfica le deniega el certificado de clasificación, fundado en que la representación de Cristo en el video viola la Ley Criminal de Blasfemia, la que impide descalificar verbalmente tanto personas como creencias o actos religiosos, como es el caso, atendido lo cual, en países como Reino Unido, ello era considerado delito. En concreto esta ley defiende la figura de Dios, Jesucristo o la Biblia, ante cualquier tipo de comentario, crítica o referencia a ellos que se haga de manera irrespetuosa. El Comité entiende que este cortometraje mezcla el éxtasis religioso con la pasión sexual, lo que, si bien puede ser de interés legítimo para el artista, es susceptible de ofender a quien lo vea, dada la manera en que se retrata a Cristo, un sujeto sagrado. El problema está, pues, no en que éste aparezca, sino en cómo aparece. El Comité interpreta que la presencia de Jesucristo tiene la única finalidad de servir como objeto sexual a Santa Teresa, «sin pretender explorar el significado de la imaginería más allá de ofrecer una experiencia erótica al espectador».

Wingrove recurre ante el Comité de Apelaciones de Video. La Comisión explica su decisión en relación con sus funciones, determinadas en el Acta de 1984, señalando que como ésta no especifica qué principios han de aplicarse para facilitar un certificado de clasificación (necesario para publicar videos), decidieron establecer ellos mismos los principios de idoneidad al efecto. Wingrove defendió su video argumentando que no existía uniformidad en la ley, ni estaban claros sus principios. Usó como argumento que películas como La vida de Brian o La última tentación de Cristo, sí que habían recibido aprobación por parte de la Comisión. La apelación fue rechazada. Wingrove decide llevar el caso ante la Comisión Europea de Derechos Humanos, la cual elevó el asunto ante el Tribunal Europeo de Derechos Humanos el 1 de marzo de 1995.

En la sentencia el TEDH recuerda que la libertad de expresión constituye uno de los fundamentos esenciales de una sociedad democrática. Sin embargo, como el párrafo 2 del artículo 10 reconoce expresamente, el ejercicio de esa libertad conlleva deberes y responsabilidades. Entre ellos, en el contexto de las creencias religiosas, puede legítimamente incluirse el deber de evitar en la medida de lo posible una expresión que es, en lo que respecta a los objetos de veneración, gratuitamente ofensiva a los demás y profanadora (Sentencia del Tribunal Europeo de Derechos Humanos, caso Wingrove con Reino Unido, párrafo quincuagésimo segundo, 25 de noviembre de 1996).

En cualquier caso, señala, ninguna restricción puede aplicarse a la libertad de expresión a menos que satisfaga la condición que establece el artículo 10.2 cuando habla de «medidas necesarias en una sociedad democrática». En este caso, precisa, la blasfemia está prevista en la ley y la interferencia del Gobierno es legítima y necesaria. El Tribunal afirma que, si bien se requiere que la ley esté formulada con la suficiente precisión como para que los interesados puedan prever las consecuencias de sus actos, 
una ley que confiera un margen de apreciación no es incompatible con esa exigencia (Sentencia del Tribunal Europeo de Derechos Humanos, caso Wingrove con Reino Unido, párrafo quincuagésimo tercero, 25 de noviembre de 1996). Asimismo, también acepta la argumentación de que las ofensas por blasfemia no se prestan, por su propia naturaleza, a una definición jurídica precisa. Ratifica así la medida adoptada por la Comisión y entiende que la interferencia busca proteger los sentimientos religiosos de los cristianos. Esta decisión está amparada en los artículos 9.2 y 10.2 del Convenio Europeo, por los cuales los derechos de libertad de expresión y de pensamiento, conciencia y religión se pueden regular, para proteger otros derechos. Admite que la Ley de Blasfemia no trata por igual a todas las religiones, no obstante, esa falta de igualdad no deslegitima las medidas tomadas en base a ésta. El Tribunal deja margen a los Estados para apreciar si dichas restricciones son necesarias en una sociedad democrática o no. Reconoce al efecto que las leyes de blasfemia se han ido derogando en Europa y hay grandes y fuertes argumentos a favor de su derogación en los países en los que aún sigue vigente. De hecho, en el mismo Reino Unido solo se ha aplicado dos veces en los últimos setenta años. No obstante, el hecho es que todavía no existe un terreno común en los ordenamientos jurídicos como para afirmar que las imposiciones de un Estado, en lo que respecta a la difusión de material que podría considerarse blasfemo, son innecesarias en una sociedad democrática e incompatibles con el Convenio Europeo de Derechos Humanos.

El Tribunal consideró que no existía un conjunto de normas morales uniforme ni un concepto homogéneo de los requisitos de «la protección de los derechos de los demás» en relación con los ataques contra las creencias religiosas en Europa, de modo que aquello que se puede considerar como una ofensa a la religión puede cambiar dependiendo del espacio y el tiempo. Por este motivo, el Tribunal considera que la justicia local está más preparada para juzgar la necesidad de la restricción que la justicia internacional (del propio Tribunal Europeo). Sin embargo, este reconocimiento no implica que deje de existir una supervisión internacional para evitar injerencias arbitrarias o excesivas. Por tanto, la tarea del Tribunal es comprobar si los motivos invocados por los Estados para justificar las medidas que interfieren con la libertad de expresión se ajustan a lo determinado en el artículo 10.2. del Convenio (Sentencia del Tribunal Europeo de Derechos Humanos, caso Wingrove con Reino Unido, párrafos quincuagésimo séptimo y quincuagésimo octavo, 25 de noviembre de 1996).

En virtud de lo razonado, el Tribunal valida como legítimas las argumentaciones del gobierno británico para la prohibición del video, en tanto su difusión podría considerarse un insulto a los sentimientos cristianos. Aunque el Tribunal reconoce que las medidas adoptadas por las autoridades equivalen la prohibición total, entiende que ello no es más que un efecto colateral, consecuencia de la negativa de Wingrove a eliminar o modificar aquellas partes que atentaban contra la Ley de Blasfemia. Sostuvo que los Estados están en mejores condiciones que un órgano internacional para 
determinar qué ofenderá en esencia a las personas, particularmente cuando las convicciones religiosas varían en el espacio y el tiempo. Considera, respecto de la blasfemia, que ésta no prohíbe la expresión de opiniones ofensivas u hostiles al cristianismo, sino más bien, por el contrario, para entender que existe insulto a la religión, éste debe ser grave. Ahora bien, el alto nivel de profanación que debe observarse, a juicio de la Corte europea, sirve como salvaguardia contra la arbitrariedad (Sentencia del Tribunal Europeo de Derechos Humanos, caso Wingrove con Reino Unido, párrafo sexagésimo a sexagésimo cuarto, 25 de noviembre de 1996).

Concluye que la justificación de la interferencia en el caso en comento era pertinente, suficiente y que las decisiones de las autoridades no eran arbitrarias ni excesivas, por lo cual no se comprobaba una violación del derecho a la libertad de expresión (Sentencia del Tribunal Europeo de Derechos Humanos, caso Wingrove con Reino Unido, párrafo sexagésimo quinto, 25 de noviembre de 1996).

Finalmente, quince años después de la sentencia, en 2011, el Comité levantó la prohibición. Por primera vez, Visiones del éxtasis se pudo distribuir legalmente en Reino Unido.

\section{Consideraciones finales}

Es manifiesta la relevancia de la libertad de expresión como un derecho fundamental que permite la libre difusión de las ideas, pensamientos y opiniones, así como su rol fundamental en la formación de la opinión pública y en el fortalecimiento de toda sociedad democrática, y en tal sentido no le es permitido al Estado limitar el ejercicio de este derecho a través de la censura previa, no obstante puedan establecerse prohibiciones en aras de resguardar el orden público y de proteger los derechos de los demás.

Por otra parte, la libertad de religión es un derecho fundamental que puede expresarse de forma individual o colectiva, supone la capacidad de toda persona para autodeterminarse en su comportamiento de acuerdo con las convicciones y creencias que tenga en el plano religioso; los enfrentamientos entre ambas garantías han sido constantes.

Tanto el sistema interamericano como el europeo, realzan y erigen a la libertad de expresión y pensamiento como un presupuesto básico y componente esencial de la sociedad democrática, que no se aplica solamente a las informaciones o ideas que se reciben favorablemente o se consideran inocuas, sino también a las que ofenden o molestan, porque así lo exigen el pluralismo y la mentalidad amplia, propios de una sociedad democrática. De igual manera, ambos entienden que, a esta función de comunicación, se añade el derecho del público de recibirla, confiriéndole a la libertad de expresión una doble dimensión, tanto individual como colectiva. Por otra parte, ambos sistemas admiten limitaciones a la misma, con carácter excepcional y restrictivo, debiendo en general obedecer a una necesidad social imperiosa. Esta mi- 
rada compartida se manifiesta al referir y aplicar la Corte Interamericana, en diversos pronunciamientos, los estándares o razonamientos del TEDH.

El análisis de las sentencias del TEDH evidencian que el Tribunal tiene en cuenta varios aspectos a la hora de decidir qué es lo que limita y qué es lo que vulnera el derecho a la libertad de expresión. En este sentido resulta interesante el desarrollo de la doctrina del «Margen de Apreciación» de los Estados, por el TEDH, pues da cabida a las particularidades de cada caso y las realidades propias de cada país, las que son mejor apreciadas por las autoridades nacionales, por lo que son éstas las primeras llamadas a decidir sobre la legitimidad de una injerencia. Ello evidencia los diversos matices que los derechos fundamentales pueden llegar a alcanzar en su interacción con otros, de diversa índole, pudiendo arribarse inclusive a resultados en sentidos opuestos, pese a tratarse de circunstancias similares, en razón precisamente a esas realidades propias de cada país, de las circunstancias del caso y del momento, así como de la normativa vigente en los respectivos ordenamientos jurídicos.

Es igualmente necesario precaver siempre el grado que se confiere a dicho margen de apreciación, toda vez que si éste es muy amplio, puede encerrar el peligro de terminar justificando, en su nombre, las injerencias de los poderes públicos y avalar situaciones que finalmente constituyen casos evidentes de censura, no obstante fundarse en la protección de creencias religiosas o en leyes vigentes del ordenamiento jurídico, como vimos tratándose de la Ley de Blasfemia, ley discriminatoria e imprecisa.

De ahí la relevancia del rol de los órganos internacionales en la labor de interpretación y protección de los derechos fundamentales. Me parece esencial, en los casos en que esta garantía pueda resultar restringida, no dejar de formularse siempre la pregunta en torno a si la injerencia a la libertad de expresión y pensamiento es realmente necesaria para esa sociedad democrática, con habida consideración, por una parte, que cuando un derecho se ejerce conforme a su esencia, a lo que forma parte de su contenido, no debiese conflictuar con otros, y por otra, a que, como señalé al inicio de estas reflexiones, y reitero al finalizarlas, hoy por hoy no puede concebirse un Estado que se precie de democrático, que dé la espalda a la libertad de expresión.

\section{Referencias}

Anderson, Gavin. (2005). Constitutional rights after globalization. Oxford: Hart Publishing.

Carbonell, Miguel. (2005) «La libertad de expresión, partidos políticos y democracia. Comentario a la sentencia JDC-393/05 del Tribunal Electoral del Poder Judicial de la Federación». Disponible en: http://www.miguelcarbonell.com

Costa, Jean Paul (2001). La Libertad de Expresión según la jurisprudencia del Tribunal Europeo de Derechos Humanos de Estrasburgo. Disponible en: http://www. corteidh.or.cr/tablas/r27016.pdf 
Espinoza ArIzA, Jelmut (2015). «El derecho a la libertad de expresión contra el derecho a la libertad religiosa. ¿Existe un derecho a blasfemar? A propósito del caso de la revista Charlie Hebdo». Lex (Facultad de Derecho y Ciencia Política), 15. Universidad Alas Peruanas.

Fernández Segado, Francisco (1990). «La libertad de expresión en la doctrina del Tribunal Europeo de Derechos Humanos». Revista de Estudios Políticos, 70.

Freixes Sanjuán, Teresa (2003 «El Tribunal Europeo de Derechos Humanos y las libertades de la comunicación». Revista de Derecho Comunitario Europeo, 15.

Grossman, Claudio (2007). «La libertad de expresión en el sistema interamericano de protección de los derechos humanos». Ponencia ofrecida en el marco del 25 Curso Interdisciplinario en Derechos Humanos. San José de Costa Rica.

Gullco, Hernán (2009). «La doctrina de la 'real malicia' y la reciente jurisprudencia de la Corte Interamericana de Derechos Humanos sobre libertad de expresión». Revista de Derecho y Ciencias Penales (Universidad San Sebastián), 13.

HäBerle, Peter (2002). Pluralismo y constitución. Estudios de teoría constitucional de la sociedad abierta. Edición a cargo de E. Mikunda. Madrid: Tecnos.

Human Rights Watch (1998). Los límites de la tolerancia. Colección Nuevo Periodismo. Santiago.

OEA, Organización de Estados Americanos (1998). Informe de la oficina del relator especial para la libertad de expresión. OEA/ser.L./V./II.102, doc. 6 rev. vol. 3. Disponible en: http://bit.ly/2pdRCCZ.

Serna de la Garza, José María (2013). Globalización y derecho constitucional comparado. México: Universidad Nacional Autónoma de México - Instituto Iberoamericano de Derecho Constitucional.

\section{Sobre la autora}

María Fernanda Ekdahl Escobar es abogada de Pontificia Universidad Católica de Valparaíso y magíster en Derecho Público, con mención en Derecho Constitucional de la Pontificia Universidad Católica de Chile. Autora del libro Teoría de los Actos Propios. El deber jurídico de no contrariar conductas propias pasadas. Titulada por la Universidad de Salamanca, España, Curso de Especialización en Derecho Constitucional, «La protección de los derechos fundamentales en las democracias actuales». Abogada Analista de la Dirección de Estudios, Análisis e Investigación del Tribunal Constitucional de Chile. Su correo electrónico es mekdahl@tcchile.cl. 
La Revista de Derecho Público es publicada, desde 1963, dos veces al año por el Departamento de Derecho Público de la Facultad de Derecho de la Universidad de Chile. Su propósito es la difusión de los avances del derecho público nacional e internacional y la socialización de artículos de investigación inéditos tanto de la comunidad académicas nacional e internacional.

DIRECTORA

Ana María García Barzelatto

SECRETARIO DE REDACCIÓN

Felipe Peroti Díaz

(fperoti@derecho.uchile.cl)

SITIO WEB

revistaderechopublico.uchile.cl

CORREO ELECTRÓNICO

publico@derecho.uchile.cl

LICENCIA DE ESTE ARTÍCULO

Creative Commons Atribución Compartir Igual 4.0 Internacional

La edición de textos, el diseño editorial

y la conversión a formatos electrónicos de este artículo

estuvieron a cargo de Tipográfica

(www.tipografica.cl). 